\title{
STUDIES ON THE STIMULATION OF CATALPA BIGNONIOIDES WALT. SEED GERMINATION
}

\author{
Daniela-Sabina Poșta ${ }^{1}$, Sándor Rózsa ${ }^{2 *}$, Tincuța-Marta Gocan ${ }^{2}$ \\ ${ }^{1}$ Banat University of Agricultural Sciences and Veterinary Medicine „King Michael I of Romania" from Timisoara, \\ Faculty of Horticulture and Forestry, 119 Aradului Street, 300645 Timisoara, Romania \\ ${ }^{2}$ University of Agricultural Sciences and Veterinary Medicine, \\ Faculty of Horticulture, 400372, 3-5 Mănăş̧ur Street, Cluj-Napoca, Romania
}

Current Trends in

Natural Sciences

\begin{abstract}
Catalpa is a tree with an attractive ornamental value and compact shape. Catalpa bignonioides Walt., is a tree with heights of up to 35 meters and a large trunk. It is an exotic species in North America areal. It grows well in a warm and humid climate, on alluvial, fertile, deep, temperate soils. It has a light temperament, withstands winter frosts well, but is sensitive to late frosts. The degree of germination varies both between species and within them. Within batches of seeds of the same species varies depending on the origin, year of harvest and individual trees. There are different methods and techniques for overcoming drowsiness depending on the seeds. Various pre-treatments are used such as scarification and hot and cold aeration to stimulate the embryo. The paper presents the stimulation of seed germination at catalpa, using different concentrations of Nitragin: $0.1 \%, 0.3 \%, 0.5 \%, 0.7 \%, 0.9 \%$ and following the seed germination interval.
\end{abstract}

Keywords: Catalpa, Nitragin, seed germination.

\section{INTRODUCTION}

Catalpa bignonioides Walt. - the cigar tree, the bean tree, reaches heights of up to $35 \mathrm{~m}$ and large diameters. It is an exotic species, with an area in North America, which vegetates well in a warm and humid climate, on alluvial, fertile, deep, temperate soils. It has a light temperament, withstands winter frosts well, but is sensitive to late frosts. In green spaces it is recommended to plant in alignment on stations, boulevards or in groups on lawns in parks and public gardens. Species of this genus are propagated by seeds, in spring in greenhouses, by root cuttings. (Dumitriu-Tătăranu et al., 1960).

Following the taxonomic review study of the genus Catalpa (Family Bignoiaceae) which includes trees frequently used in green spaces, eight natural species and two hybrid species were recognized (Olsen and Kirkbride, 2017).

Species of this genus are described by (Meyer, 1907; Clarke, 1988; Dirr, 2009; Grimshaw and Olsen, 2011) as very beautiful, with white, yellow flowers arranged in racemes or pink in corymbs that persist long in bloom. The flowering period is July and August, the corolla has a bell-shaped. The leaves are large (10-20 cm long) heart-shaped placed opposite, long petiolate. The fruits are 


\begin{tabular}{|c|c|}
\hline & \\
\hline $\begin{array}{l}\text { Current Trends in Natural Sciences (on-line) } \\
\text { ISSN: 2284-953X } \\
\text { ISSN-L: 2284-9521 }\end{array}$ & $\begin{array}{r}\text { Current Trends in Natural Sciences (CD-Rom) } \\
\text { ISSN: 2284-9521 } \\
\text { ISSN-L: 2284-9521 }\end{array}$ \\
\hline
\end{tabular}

long (20-35 cm), cylindrical capsules that include numerous winged, flat, tomentose seeds at both ends. The fruits remain on the branches throughout the winter (Belot 1985; Seneta 1987).

C. bignonioides Walt. is used in the treatment of asthma (Csapody and Toth 1982) and in road alignments (Chadaeva et al. 2019).

In the south-eastern part of Romania, $C$. bignonioides Walt. shows a frequency of powdery mildew (Erysiphe elevata) fungus native to North America. (Chinan and Mânzu 2018).

The aim of this paper was to stimulate the germination of catalpa seeds, using different concentrations of Nitragin and to follow the germination interval of the seeds.

\section{MATERIALS AND METHODS}

The researches took place in the laboratory of the Arboriculture discipline from the Didactic and Research Base of the University of Agricultural Sciences and Veterinary Medicine of Banat "King Mihai I of Romania" from Timisoara, Romania.

The fruits of $C$. bignonioides Walt. were harvested on October 15 from the University Park and stored at a temperature of $4{ }^{\circ} \mathrm{C}$.

This experiment was performed in order to accelerate the germination of $C$. bignonioides Walt. seeds, considered one of the species with great ornamental value in the park. The seeds were prepared by removing the heads (wings) of the seeds.

The experiment was set up on March 1, 2019 in controlled environment conditions at a temperature of $22{ }^{\circ} \mathrm{C}$, the seeds were treated with Nitragin in different concentrations (figure 1).

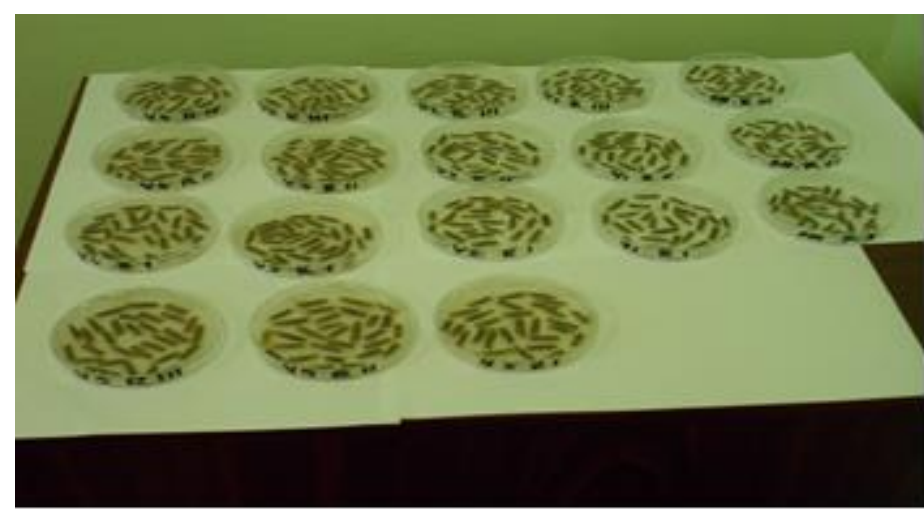

Figure 1. Conducting the experience. Seeds of C. bignonioides Walt. treated with Nitragin.

Nitragin contains pure bacterial culture in the active state, infectively specific to a single species of leguminous plant, it is presented in closed $250 \mathrm{ml}$ bottles with non-hydrophilic cotton wool filter plug and plastic stopper. The amount needed to treat the seeds differs, depending on the treated plant species. The group of biopreparations type for agriculture, Nitragin includes pure industrial crops of root bacteria, species or breeds to achieve symbiosis in legumes. Inoculated as a bacterial suspension on seeds or directly in the soil, they determine the massive formation, on the root system, of intensely efficient and long-active nodules, which materializes by increasing the potential for biological fixation of molecular nitrogen and minimizing or excluding nitrogen fertilization. The biochemical processes that take place within this symbiosis are completed by the appearance of growth regulators, phosphate mobilization, resistance to certain mycoses, increase in protein content accompanied by changes in the percentage ratio of essential amino acids; at the 


\section{Current Trends in Natural Sciences}

Vol. 10, Issue 20, pp. 172-178, 2021

https://doi.org/10.47068/ctns.2021.v10i20.023

Current Trends in Natural Sciences (on-line)

same time, the nitrogen reserve from the biological capture cycle after the crop harvest is increased in the soil.

Application procedure. For the application of the preparation, only the mucilage formed on the surface of the nutritive environment is important. 2 hours before use, the cotton wool plug was removed and the distilled water was poured to $3 / 4$ from the capacity of the bottle. The bottle was shaken well so that the mucilage came off, and it mixed as well as possible with water. The mixture was poured into a clean vessel with a capacity of $250 \mathrm{ml}$. The bottle was rinsed with clean water several times until all the mucilage was removed. In the $250 \mathrm{ml}$ vessel was collected everything that was washed from the bottle, and at the end, water was added up to the $250 \mathrm{ml}$ mark, which was then filtered and diluted to concentrations of $0.1 \%, 0.3 \%, 0.5 \%, 0.7 \%$, and $0.9 \%$ with which the seeds were treated.

A two-factor experiment was organized, as follows:

$>$ Factor A - germination period: a1 - date of March 16; a2 - date of March 17; a3 - March 18 and a4 - March 21 (Control).

- Factor B - Stimulation of seed germination with Nitragine: b1 untreated (Control), b2 concentration of $0.1 \%$, b3 concentration of $0.3 \%$, b4 concentration of $0.5 \%$, b5 concentration of $0.7 \%$ and b6 concentration of $0.9 \%$.

\section{RESULTS AND DISCUSSIONS}

Figure 2 shows the situation in which the seeds were not treated. The first seeds that germinated appear starting with March 13 in the same conditions. Then, on the 16th there is a slight decrease, after which it increases again and until the 21st of March where again the decrease is obvious.

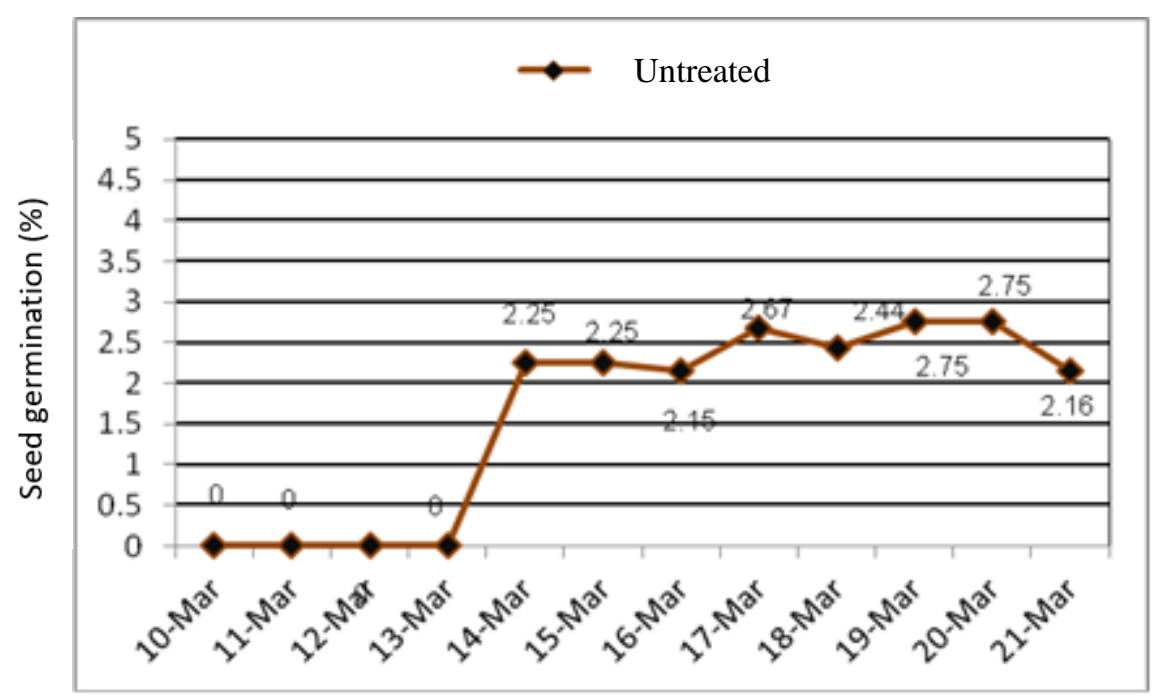

Figure 2. Untreated C. bignonioides Walt. germinated seeds, between March 10-21.

If the seeds were moistened with Nitragin at a concentration of $0.1 \%$ the seeds began to germinate faster with one day (Figure 3), but on March 16 there is also a limit where the germination decrease. 


\section{Current Trends in Natural Sciences}

Vol. 10, Issue 20, pp. 172-178, 2021

https://doi.org/10.47068/ctns.2021.v10i20.023

Current Trends in Natural Sciences (on-line)

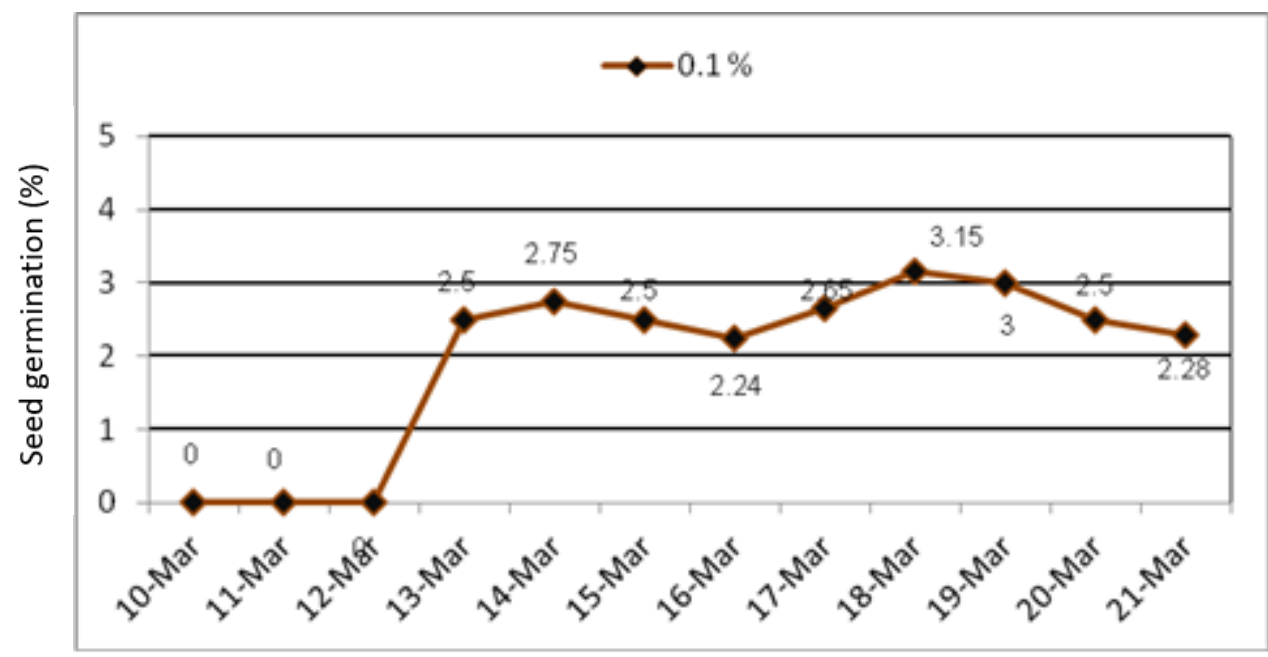

Figure 3. C. bignonioides Walt. seeds germination at a concentration of 0.1\% Nitragin, between March 10-21

Following the situation represented in figure 4, for the concentration of $0.3 \%$ Nitragin, it can be seen that in this case the seeds germinate a day earlier, but there is that germination limit on March 15.

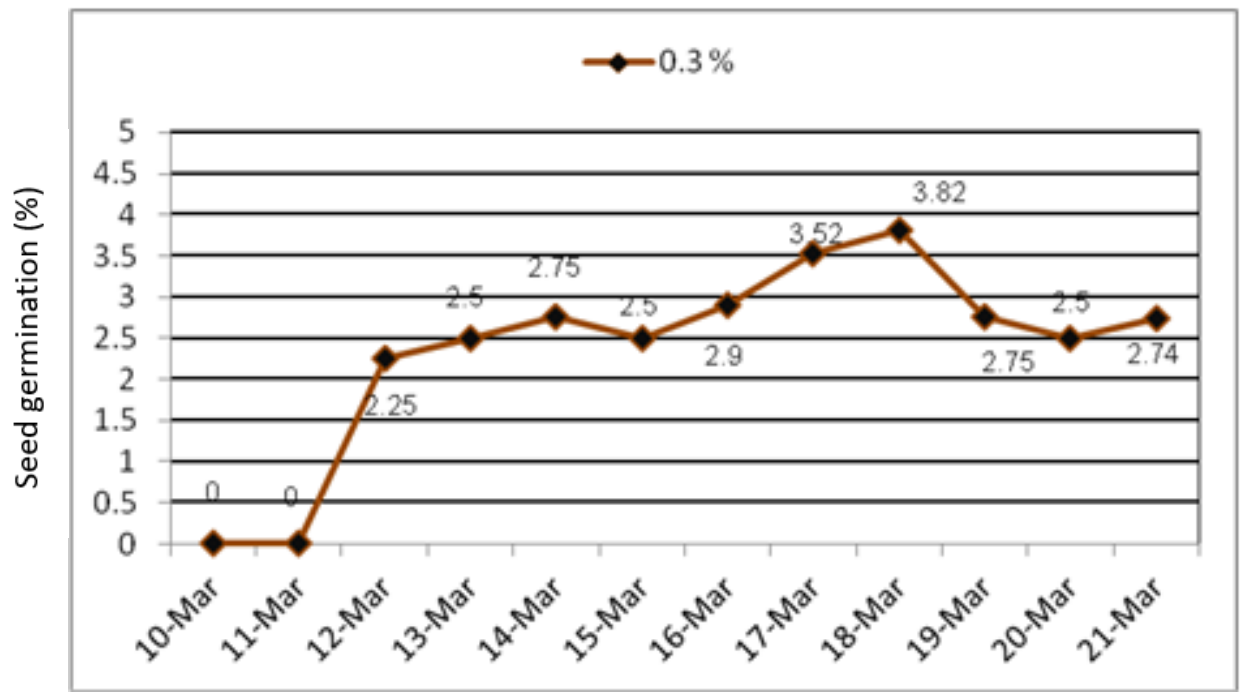

Figure 4. C. bignonioides Walt. germinated seeds, at a concentration of 0.3\% Nitragin, between March 10-21

In the situation where the concentration of $0.5 \%$ Nitragin was applied, the first seeds germinate on March 10, and the slight decrease appears on March 14, then again, we have an increase until March 19, where there is a second germination decrease, followed by an increase again (figure 5). 


\section{Current Trends in Natural Sciences}

Vol. 10, Issue 20, pp. 172-178, 2021

https://doi.org/10.47068/ctns.2021.v10i20.023

Current Trends in Natural Sciences (on-line)

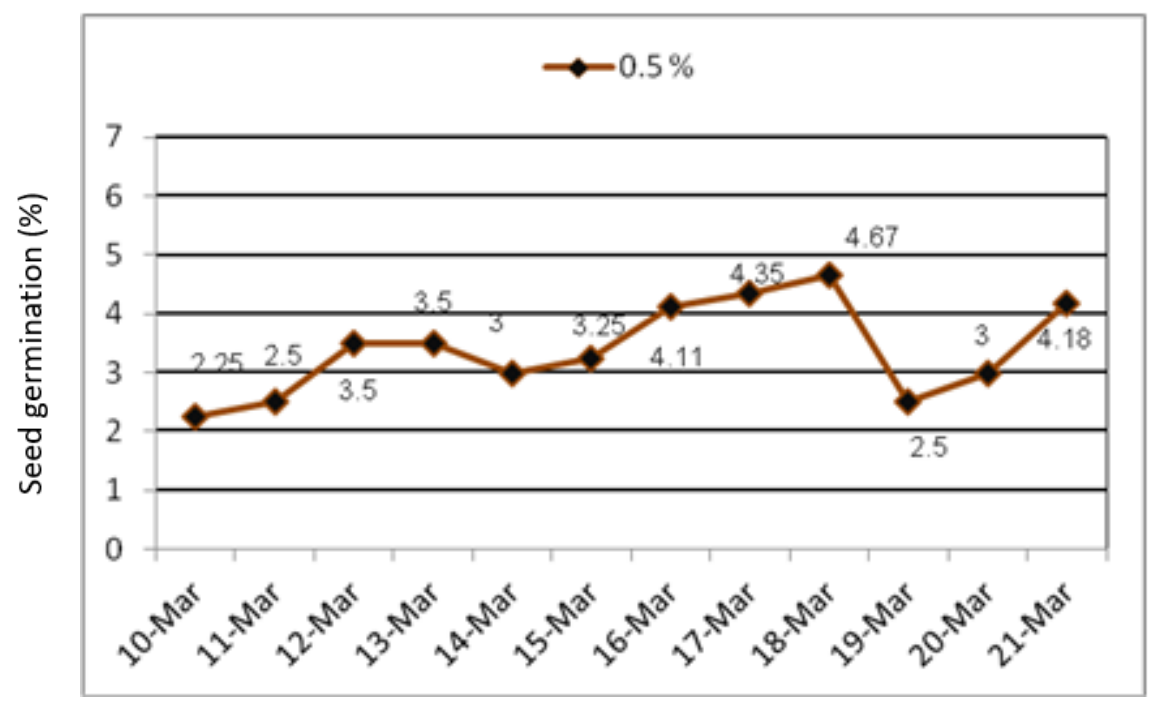

Figure 5. C. bignonioides Walt. germinated seeds, at a concentration of 0.5\% Nitragin, between March 10-21

If the concentration of Nitragin was increased to $0.7 \%$ (figure 5), it seems that we have a decrease and the first germinated seeds appear on March 11, with the germination decrease on March 15. Comparing the number of germinated seeds with those treated at the concentration of $0.5 \%$ Nitragin, shown in Figure 5, their number shows a slight decrease.

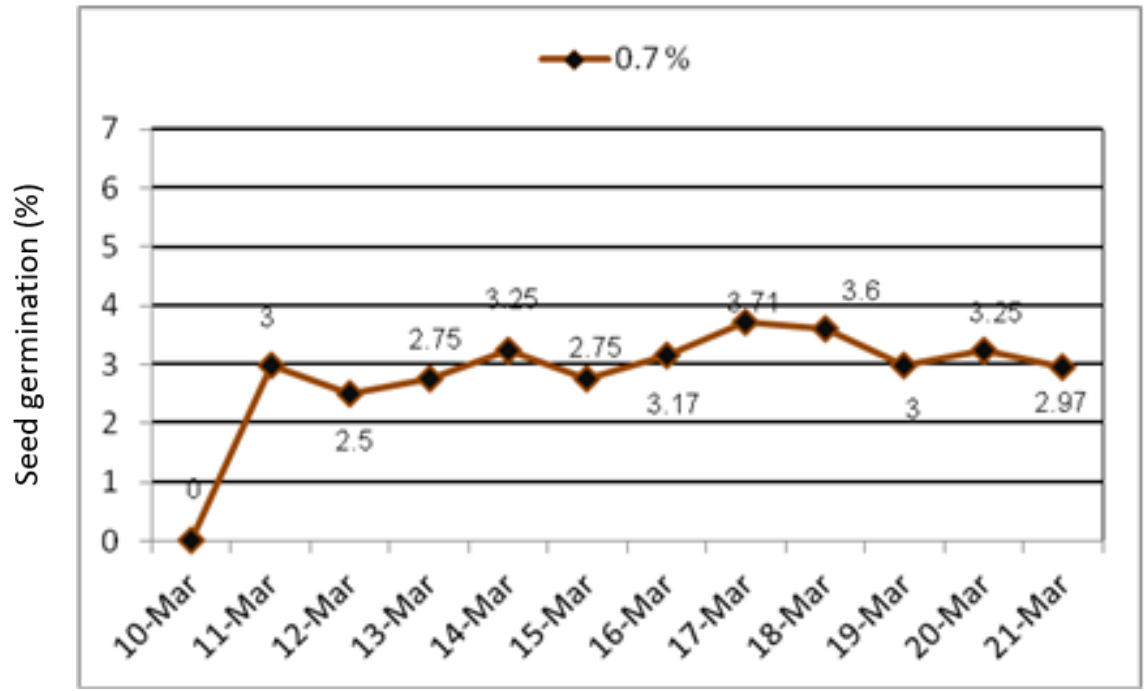

Figure 6. C. bignonioides Walt. germinated seeds, at a concentration of 0.7\% Nitragin, between March 10-21

At a concentration of $0.9 \%$ Nitragin, the $\mathrm{C}$. bignonioides Walt. seeds begin to germinate on March 11 , but over the entire period, the number of germinated seeds decreases slightly. It can be seen that that germination decrease appears on March $16^{\text {th }}$ (figure 7). 


\section{Current Trends in Natural Sciences}

Vol. 10, Issue 20, pp. 172-178, 2021

https://doi.org/10.47068/ctns.2021.v10i20.023

Current Trends in Natural Sciences (on-line)

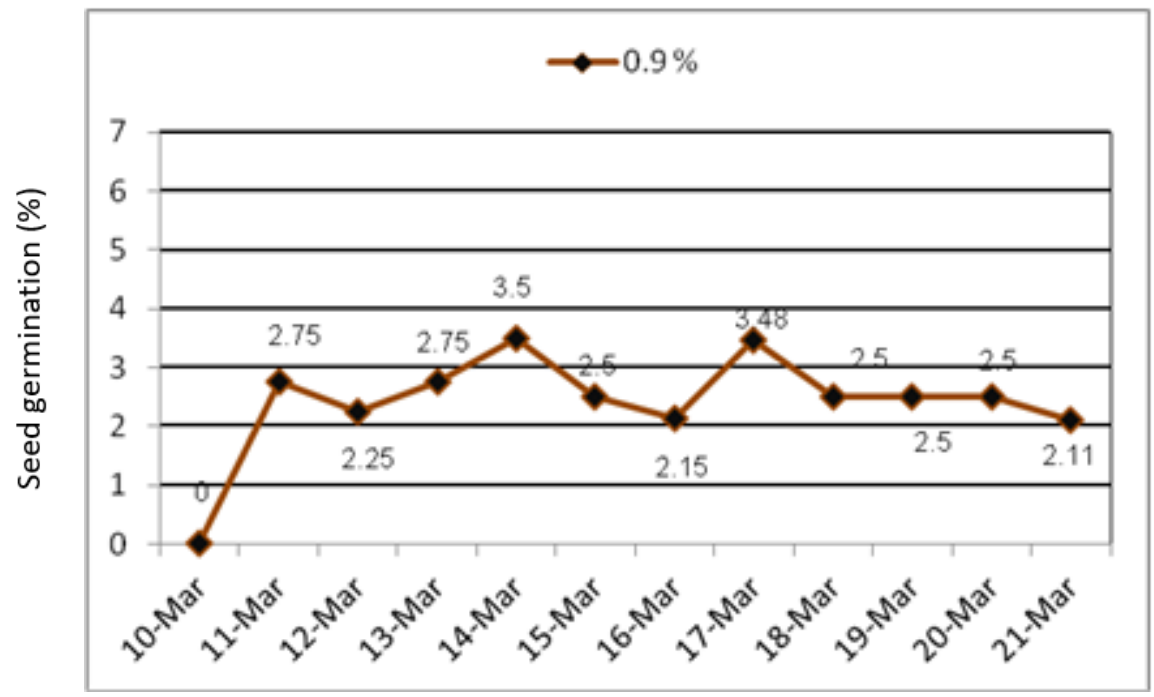

Figure 7. C. bignonioides Walt. germinated seeds, at a concentration of 0.9\% Nitragin, between March 10-21

The synthesis of the results presented in figure 8 shows that the concentration of $0.5 \%$ is the best in the experiment performed on the genus Catalpa in laboratory conditions.

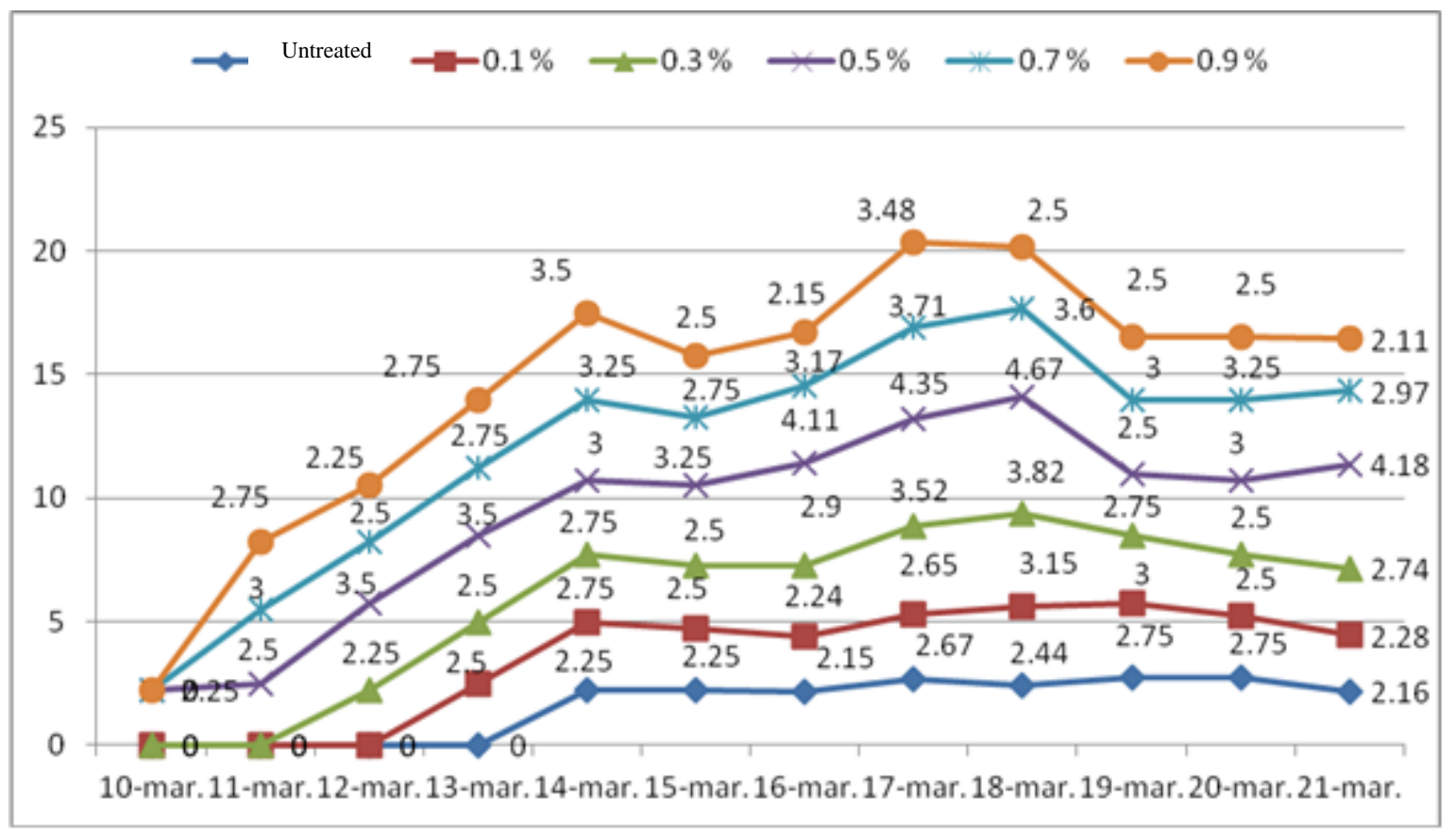

Figure 8. The synthesis of C. bignonioides Walt. germinated seeds results

Over a longer period of time, starting with March 16, they have a higher percentage of germination, compared to all other experimental variants.

Increasing the concentration of Nitragin helps to germinate earlier, but the number of germinated seeds has been decreasing. 


\section{Current Trends in Natural Sciences}

Vol. 10, Issue 20, pp. 172-178, 2021

https://doi.org/10.47068/ctns.2021.v10i20.023

Current Trends in Natural Sciences (on-line)

ISSN: 2284-953X

Current Trends in Natural Sciences (CD-Rom)

ISSN: 2284-9521

ISSN-L: 2284-9521

ISSN-L: 2284-9521

\section{CONCLUSIONS}

Following this experience, the following can be concluded:

- seed preparation before germination influences not only the germination capacity, but also the subsequent evolution of the seedlings, by stimulating some vegetative growth processes, optimal results being recorded when the seeds were treated with $0.5 \%$ Nitragin.

- Increasing the dose of Nitragin over $0.5 \%$ helps to germinate the seeds earlier, but the number of germinated seeds has been decreasing.

\section{REFERENCES}

Belot, A. (1985). Paulownia et Catalpa. Jardins Fr. 10, 296-298.

Chadaeva, V.A., Shhagapsoev, S.H., Tsepkova N.L., Shhagapsoeva, K.A. (2019). Materials for the Blacklist of the Central Caucasus Flora (Kabardino-Balkar Republic): Part II, Russian Journal of Biological Invasions 10, 269281.

Chinan, V.C., Mânzu, C.C. (2018). Distribution, Incidence and Severity of the Catalpa Powdery Mildew Caused by Erysiphe elevata in North-Eastern Romania. Notulae Scientia Biologicae, 10(4), 614-617. https://doi.org/10.15835/nsb10410374

Clarke, D.L. (1988). Bean's trees and shrubs hardy in the British Isles, ed. 8. John Murray, London.

Csapody, V., Toth, I. (1982). Bignoniaceae-Bignonia family. In: A colour atlasd of flowering trees and shrubs. Akademia Kiado, Budapest pp. 264-268.

Dumitriu-Tătăranu, I., Paşcovschi, S., Beldie, AL., Spîrchez, ST., Radu., Hulea, A., Clonaru, Al., Ocskay, S. (1960). Arbori și arbuști forestieri și ornamentali cultivați în RPR. Editura Agro-silvică, București.

Grimshaw, J., Olsen, R.T. (2011). Tree of the year: Chinese species of Catalpa Scop. International Dendrology Society Yearbook 26-59.

Meyer, F. N. (1907). Catalpa bungei. U.S.D.A. Bureau of Plant Industry Bulletin 106, 73.

Olsen, R.T., Kirkbride, J.H. (2017). Taxonomic revision of the genus Catalpa (Bignoniaceae). Brittonia 69, 387-421 https://doi.org/10.1007/s12228-017-9471-7

Seneta, W. (1987). Rodzaj Catalpa L. In Dendrologia. PWN Warszawa, pp 544-546. 